\title{
Breaking the Code. John Wallis AND THE POLITICS OF CONCEALMENT
}

Philip Beeley

If the life of John Wallis were a novel, its closing chapter would perhaps be the most revealing of all. Approaching the end of his eighty-sixth year, the great Oxford mathematician and theologian prepared the manuscript of what he hoped might become yet another testament to his achievements in addition to those documented by the many letters, articles, and books which had appeared in print during his lifetime, not a few of which helped shape the course of seventeenthcentury science. But the prospective book, over whose manuscript he toiled during his final days would be a monument to his learning quite different from works such as the Arithmetica infinitorum or the Mechanica sive de Motu, the Theological Discourses or the Grammatica linguae Anglicanae.

The publication which Wallis planned, right down to detailed instructions to the printer on how the manuscript should be typeset, was a selection of letters he had deciphered over the last thirty-four years. ${ }^{1}$ It was to contain eighty-three letters in all, partly written in plain text, partly in cipher, together with the eighteen different keys he had discovered in them (see Figure 1). Remarkably, the final letter in the collection is dated 19 August 1703 (new style) and takes its context from the War of Spanish Succession which had begun two years earlier: the French commander, Marshal Claude Louis Hector de Villars, writes to Louis XIV, informing him of the condition of his troops at their camp in Dillingen on the Donau. In view of the need to convey the intercepted letter across half the continent of Europe, a difficult journey at the best of times, it could scarcely have reached Wallis in Oxford before the end of September. No doubt, he would, as usual, have set about deciphering the text immediately upon its receipt. And this despite increasing frailty and near blindness in one eye. As he would perhaps have sensed, time

The book manuscript is now Oxford, Bodleian Library, MS Eng. misc. c. 382. Wallis begins his instructions thus: »If these Deciphered letters come to be printed; I think it best that the Letters as they are, part in Cipher \& part in plain words, be printed in pretty large letter; \& the Deciphering in a smaller letter between the lines; each word, letter or syllable just over the number to which it belongs; $\&$ to that purpose, if such word be longer then to stand over its number, the numbers be printed at such distance as to make roome for it.« (p. iv). 
was pressing. He died in Oxford on 28 October 1703 and was later interred in the University Church of St Mary. ${ }^{2}$

Fig. 1: Part of Wallis's list of deciphered letters contained in the collection he prepared shortly before his death in 1703. Oxford, Bodleian Library, MS Eng. misc. c. 382, p. vi.

At the time of his death Wallis was not only the incumbent Savilian professor of geometry and the Keeper of the Archives of the University of Oxford, but also, together with his grandson and would-be successor William Blencowe, the first holder of the post of decipherer in the office of the Secretary of State. ${ }^{3}$ This was a new post which had only been created towards the end of the reign of William III, in April 1701, and which reflected the importance that monarch placed on surveillance and intelligence in the conduct of his policy at home and abroad. ${ }^{4}$ Although official status as decipherer came late, Wallis had in fact been employed by government officers in the breaking of codes for over sixty years since the Civil Wars, through the Commonwealth and the Protectorate to the Restoration and beyond. ${ }^{5}$ Nor was this a one-sided relationship. Wallis's skill as a code-breaker was of mutual benefit both to him and to his various employers. More than anything else it set him on his academic career in Oxford and enabled him to steer a remarkably steady course through the heavy seas of politics and religion in seventeenth-century England.

The story of Wallis as a decipherer is as complex as it is long. For reasons of brevity I shall be focus on three aspects only. First, I will look at the historical background to Wallis's earliest endeavours in code-breaking and seek to correct some enduring misunderstandings as to the nature of his collaboration with parliament during the Cromwellian era. Second, I shall consider the impact of Wallis as a decipherer in the broader context of the Republic of Letters, with particular regard to his later efforts at establishing a reputation for himself in this field alongside his already established reputation primarily as a mathematician. As we will see, Wallis does not

2 See E. Lhwyd to T. Smith, 12/[22] November 1703, Oxford, Bodleian Library, MS Smith 51, 15: »There was no Oration nor Sermon at Dr Wallis's funeral nor any remarkable solemnity at all.« All dates in this chapter are given old style except where otherwise stated.

3 London, The National Archives, SP 44/348, f. 238; Calendar of Treasury Books XVI (1700-1701), London 1938, p. 243, 248; John Christopher Sainty (ed.): Officials of the Secretaries of State 1660-1782, London 1973, pp. $59,66,114$.

4 See S. P. Oakley: The Interception of Posts in Celle, 1694-1700, in: Ragnhild Marie Hatton/John Selwyn Bromley (eds.): William III and Louis XIV. Essays 1680-1720 by and for Mark A. Thomson, Liverpool 1968, pp. 95-116.

5 See Alan Marshall: Intelligence and Espionage in the Reign of Charles II, 1660-85, Cambridge 1994, pp. $93-$ 595. 
shy away from demonstrating his intellectual prowess as a cryptographer, while at the same time being circumspect as to reveal little or nothing of the methods he employed. Indeed, as I shall argue, this combination of public display and official secrecy was essential to his professional ethos and self-conception as scholar and savant. Questions of status and reputation are also central to my third concern. Following the Glorious Revolution of $1688-9 / 89$, increasingly professional demands were made on Wallis as a decipherer, yet without there being any regulated form of remuneration for his services. Caught between his unfailing sense of loyalty to the state on the one side, and his awareness of the enormous political weight of the intelligence he was providing on the other side, Wallis confronts the unfulfilled promises of senior officeholders in government with stylistic and argumentative brilliance. Here more than at any other time in his life, Wallis reflects on his standing as a university professor and on his intellectual legacy as a whole. In conclusion I will suggest that Wallis's services as a decipherer not only afford us important insights into the significance of codes and code-breaking in the political life of seventeenth-century England and of its allies, but also enable us to achieve a deeper understanding of the ways in which unseen social and political forces could frustrate even the best prepared strategies for academic or ecclesiastical preferment.

\section{A Supper of Great Consequence}

The beginning of Wallis's career as decipherer is well documented. Having completed his undergraduate studies at one of the great centres of Puritan learning in his day, Emmanuel College, Cambridge, and unable to gain a fellowship there or elsewhere, he followed many of his young contemporaries into private chaplaincy, serving first Sir Richard Darley at Buttercrambe in Yorkshire, and then Lady Mary Vere at Castle Heddingham in Essex and at Hackney. ${ }^{6}$ As Wallis recalls, one evening around the beginning of January 1642/3 43 a chaplain to Sir Willian Waller, possibly Thomas Jackson, ${ }^{7}$ attended supper at Lady Vere's London residence. During the

6 Christoph J. Scriba: »The Autobiography of John Wallis, F. R. S. «, in: Notes and Records of the Royal Society of London 25 (1970), pp. 17-46, 31. As political and religious opponents of the personal rule of Charles I, the Darley family and Mary Vere can be found connected through a number of Protestant projects in the 1630s. See Jason T. Peacey: »Seasonable Treatises: a Godly Project in the 1630s«, in: English Historical Review 113 (1998), pp. 667-79679; Felicity Heal/Clive Holmes: The Gentry in England and Wales, 1500-170d, Basingstoke/London 1994, p. 366.

7 See Anne Laurence: Parliamentary Army Chaplains, 1642-1651 (= Royal Historical Society Publications 59), Woodbridge 1990, pp. 27, 32. 
meal, Waller's chaplain mentioned a letter written in cipher which had recently been intercepted from the royalist side after the taking of Chichester at the end of December 1642 of whose content nothing could be made. Wallis boldly declared his willingness to try to decode the letter and it was subsequently fetched for him. Within a few hours and before sleeping that night he succeeded in producing a solution:

$\gg$ It was about ten a clock when we rose from Supper. I then withdrew to my chamber to consider of it. And by the number of different Characters therein, (not above 22 or 23 :) I judged that it could not be more than a new Alphabet, and in about 2 hours time (before I went to bed) I had deciphered it; and sent a Copy of it (so deciphered) the next morning to him from whom I had it. And this was my first attempt at Deciphering. $\ll^{8}$

As Wallis explains further, this unexpected success on a cipher employing mono-alphabetic substitution »was then looked upon as a great matter «. ${ }^{9}$ Soon afterward, he was pressed to try another cipher, sent by the former secretary of state, Sir Francis Windebank (1582-1646), then in exile in France, to one of his sons in England. ${ }^{10}$ This was altogether a more difficult cipher, numerically based, a mixed nomenclature of the type perfected by the great French cryptologist Antoine Rossignol. ${ }^{11}$ In their basic structure these ciphers consisted in a plain code or cipher alphabet with homophones alongside word or syllable substitutions. Thus with the help of such a nomenclature words and names could be encoded for which there was no direct code correspondence. Sometimes additional symbols or numbers were integrated in order to conceal the relative frequency of certain words or of certain combinations of letters. Conversely, the

Scriba: »Autobiography of John Wallis«,pp. 37-838. See also Charles Webster: The Great Instauration. Science, Medicine and Reform 1626-1660, London 1975, p. 40.

9 Scriba: »Autobiography of John Wallis«, p. 38: »This unexpected success, on an easy Cipher, was then looked upon as a great matter; and I was somewhile after pressed to attempt one of another Nature; which was a Letter of Mr Secretary Windebank, then in France, to his Son in England, in a Cipher hard enough, and not unbecoming a Secretary of State. It was in Numeral Figures, extending in number to seven hundred, with many other Characters intermixed. But not so hard as many that I have since met with. « See also Wallis's account in Oxford, Bodleian Library, MS Eng. misc. e. 475, iii: »After this my first attempt, a second intercepted letter was brought to me (which was the second Cipher that I had ever seen:) which was a very good Cipher. It was a Letter of Secretary Windebank (then fled into France for safety) to his Son then in England. Who (having been Secretary of State to King Charles the first) understood the business of Cipher very well: and I have not met with many better than that was. «

10 See London, British Library, MS Add. 27382, f. $239^{\mathrm{r}}-244^{\mathrm{v}}$. The encoded letter, sent from Paris in 1640 , is f. $239^{\mathrm{r}}-242^{\mathrm{v}}$. The deciphered letter is f. $243^{\mathrm{r}}-244^{\mathrm{v}}$.

11 See David Kahn: The Codebreakers. The stery Story of secret Secret writing Writing, New York 1996, pp. 15765165; Lucien Bély: Espions et embassadeurs-Ambassadeurs au p. 154; Peter Pesic: »Secrets, Symbols, and Systems. Parallels between Cryptanalysis and Algebra, 1580$1700 \ll$, in: Isis 88 (1997), pp. 674-92692, 685. 
recognition of patterns of frequency was without doubt one of the most reliable tools of the decipherer.

Like most of the encoded letters with which Wallis subsequently dealt, the Windebank letter was a numerical substitution cipher, employing over seven hundred different combinations. Only after he had made a number of attempts, spread out over several months, was he able to break the code. The importance he later attached to this achievement can be gauged by the numerous copies he subsequently made of the cipher and its solution. When training his grandson in the art of deciphering later in his life, he used precisely this letter as a test of his ability. And this is not surprising. More than any other of his deciphering tasks this early success helped Wallis to make his name as someone skilled in code-breaking.

As Wallis's description of the fateful supper in January 1642/3/43 reveals, Lady Vere was ih close contact with other Godly opponents to the crown. Apart from her own political persuasion this was principally through the marriage of her daughters, especially her daughter Anne, who was married to the parliamentary army commander Thomas Fairfax (1612-71-1671). ${ }^{12}$ Vere was a renowned patron of Puritan clergy and Wallis's immediate predecessor as her private chaplain Kommentiert [PS32]: Anm., gelbe Hinterlegung: vor der Zahl ein p. einfügen? had also studied at Emmanuel College. ${ }^{13}$ Waller, too, had connections to that college, but in Puritan circles this was almost to be expected. A good ten years before reaching the pinnacle of his military career, in 1642, Waller was one of a group of men, including Robert Greville, Nathaniel Rich, and Wallis's former tutor, Benjamin Whichcote, which had given support to

12 See George William Johnson (ed.): The Fairfax Correspondence. Memoirs of the Reign of Charles the First, 2 vols., London 1848, vol. I, 295. Vere's letters exchanged with Thomas Fairfax and with Ferdinando Fairfax, his father, provide insight into the depth of her involvement in contemporary religious and political affairs. See especially vol. I, pp. 309-11311, 320-1321. See also Webster: The Great Instauration, p. 40.

13 Samuel Rogers (1613-421642), who like Wallis had attended Felsted School in Essex, before entering Emmanuel College became chaplain to Mary Vere in 1637 and appears to have remained in this position until 1642. See Tom Webster/Kenneth Shipps (eds.): The Diary of Samuel Rogers, 1634-1638, Woodbridge 2004, pp. xxxviii-xl, xlviii. 
Samuel Hartlib in his efforts to provide education to poor scholars. ${ }^{14}$ He also supported Matthew Poole's similar scheme in the 1650 s, with which Wallis was likewise involved. ${ }^{15}$

Wallis was still in the employment of Lady Vere when, at the end of 1643, he was appointed by the House of Commons to be assistant to the two scribes already serving the Westminster Assembly of Divines, and faithfully recording its proceedings. ${ }^{16}$ This appointment was made upon a representation of the Westminster Assembly itself and it is possible that Anthony Burgess, an active member and another of Wallis's former tutors in Cambridge was involved. ${ }^{17}$ There he probably met for the first time some of those divines with whom he would later have more intensive exchanges, including the Presbyterian Anthony Tuckney and the Independent Philip Nye. It is likely that he also encountered there the Presbyterian parliamentarian Henry Wilkinson, otherwise known as Dean Harry, who became an influential parliamentary visitor to the University of Oxford in 1647. Wilkinson and Wallis corresponded occasionally into the 1690s. ${ }^{18}$ Of his immediate colleagues, the scribes Adoniram Byfield and Henry Roborough, the former had also been an undergraduate at Emmanuel College, while the latter would eventually join Wallis in his opposition to the trial and execution of Charles I. ${ }^{19}$

14 Webster: The Great Instauration, pp. 41-242. Waller's scheme for a reformation of schooling and welfare provision in Sussex was supported amongst others by Hartlib and Cheney Culpeper. Hartlib prposed a similar scheme to Waller for Hampshire. See Mike J. Braddick/Mark Greengrass (eds.): »The Letters of Sir Cheney Culpeper (1641-1657)«, in: Camden Miscellany 33 (1996), pp. 105-402, 127-8128, 252. Waller's name is also found on the list of those who provided financial support to John Dury in his efforts to secure ecclesiastical peace. On this aspect of Waller's biography see George H. Turnbull: Hartlib, Dury and Comenius. Gleanings from Hartlib's papers Papers, London 1947, p. 187.

15 See Matthew Poole: A Model for the Maintaining of Students of Choice Abilities at the University Principally in Order to the Ministry, London [1658]. On Wallis's involvement with this scheme see Philip Beeley/Christoph J. Scriba (eds.): The Correspondence of John Wallis (1616-1703), 8 vols. (4 published), Oxford 2003 ff., vol. I, pp. 533-8538, 554-5555, 569-70570, 578-80580.

16 Scriba: »Autobiography of John Wallis«, pp-. 31-737.

17 See House of Commons Journal 3, 344 (18 December 1643).

18 See William M. Hetherington: History of the Westminster Assembly of Divines, New York ${ }^{5} 1890$, pp. 1035105, where a complete list of the original 151 members of the Assembly is found.

19 See Chad B. van Dixhoorn (ed.): The Minutes and Papers of the Westminster Assembly, 1643-1652, 5 vols., Oxford 2012, vol. I, pp. 176-8178. Roborough, who at the time of his appointment was a minister in London, had studied at Jesus College, Cambridge, while Byfield had been educated at Emmanuel College. Immediately prior to being made scribe to the Westminster Assembly, he had served as chaplain to Sir Henry Cholmondeley's regiment in the earl of Essex's army.
Kommentiert [PS33]: Anm., gelbe Hinterlegung: vor der Zahl ein p. einfügen? 


\section{Presbyterian ascendency}

Already by the end of 1643 England would have appeared set on a course in which Presbyterianism was to be established as the legal religion of the land.$^{20}$ The reforms proposed by the Westminster Assembly would see the Book of Common Prayer replaced by the Directory of Worship, the Thirty-nine Articles supplanted by the Confession of Faith, and as the Form of Church Government the Presbyterian system established in place of Episcopacy. ${ }^{21}$ The signing of the Solemn League and Covenant in the late summer of 1643 would have been considered as confirmation of this course. These were also ideal conditions for advancement for the young, moderate Presbyterian John Wallis. Early in 1644, he was one of nine men nominated as fellows at Queens' College, Cambridge, by the parliamentarian and army officer Edward Montagu, second Earl of Manchester, who had been charged with regulating the University. ${ }^{22}$ Montagu was a lay member of the Westminster Assembly and would therefore have been acquainted with Wallis's work personally. Nominated alongside Wallis was the Platonist and mathematician John Smith, with whom he would exchange a series of letters on topics arising from Descartes' Géometrie, in particular concerning the rules for resolving cubic equations, in November and December 1648. ${ }^{23}$ Another member of the Westminster Assembly, the eminent Presbyterian Herbert Palmer, who was involved in drafting its Shorter Catechism, was appointed by the Earl of Manchester to the post of President of Queens' College. ${ }^{24}$ After his death in 1647, he was succeeded by the Presbyterian Thomas Horton, another of Wallis's former tutors at Emmanuel,

20 However, it was not until parliament passed legislation on the form of church government to be used in the Church of England, on 29 August 1648 (old style), that Presbyterianism was confirmed in its position as the one established ecclesiastical system of England. See Journal of the House of Lords 10, pp. 461-2462; Leland H. Carlson: »A History of the Presbyterian Party from Pride's Purge to the Dissolution of the Long Parliament«, in: Church History 11 (1942), pp. 83-122, 98.

21 Hetherington: History of the Westminster Assembly, pp. 152-64164, 350-80380. Carlson: »History of the Presbyterian Party«, p. 84; Ethyn Williams Kirby: »The English Presbyterians in the Westminster Assembly«, in: Church History 33 (1964), pp. 418-28428, 421; Tai Liu: Discord in Zion: The Puritan Divines and the Puritan Revolution, 1640-1660, The Hague 1973, pp. 48-949.

22 John Twigg: A History of Queens' College, Cambridge 1448-1986, Woodbridge 1987, pp. 57, 62, 100-1101; William George Searle: The History of the Queens' College of St Margaret and St Bernard in the University of Cambridge, 2 vols., Cambridge 1867-711871, vol. II, pp. 547-8548. They had been deemed suitable fodr nomination after examination by the Westminster Assembly.

23 See Wallis to Collins, 8/[18] April 1673, Correspondence of John Wallis IV, pp. 176-9179, and Wallis to Collins, 12/[22] April 1673, id., pp. 179-87 $\underline{187 .}$.

24 Searle: History of the Queens' College, II, pp. 539-40 $\underline{540}$; Twigg: History of Queens' College, pp. 54-5 $\underline{55}$. 
while Wallis himself published A Brief and Easie Explanation of the Shorter Catechisme (1648) according to the principles of presentation developed by Palmer..$^{25}$

After his marriage, a year later, Wallis had to resign his fellowship, but he was soon presented with the sequestrated living of St Gabriel, Fenchurch. ${ }^{26}$ This was the time when, according to Wallis, he became acquainted with a group of men, including John Wilkins, Jonathan Goddard, Francis Glisson, and Theodore Haak, who met regularly to discuss their shared interest in experimental philosophy, which meetings, rather than the more famous gatherings later in Oxford, he always saw as being the true origins of the Royal Society. ${ }^{27}$ As the receipt of the sequestrated living makes clear, Wallis was still benefiting from the Presbyterian ascendancy and indeed in April 1647 he was one of ten ministers appointed as Trier by the House of Commons, in his case to examine and approve elders in the ninth Classis of London. ${ }^{28}$ However, the fortunes of English Presbyterianism changed dramatically in 1647-8/48, as the army and the Independents in parliament combined effectively to curb their power. Negotiations between Presbyterians and the King, with a view to checking the army, following the failure of the invasion by the Scots in 1648 were met by the exclusion of all those willing to pursue that course through Pride's Purge, so that by February 1649 Presbyterianism as a parliamentary force was effectively destroyed. ${ }^{29}$

Wallis's own fortunes could not fail to be caught up in these developments. While those Presbyterian leaders who were most inimical to the army were imprisoned or fled the country, others less radical chose the pulpit of the written word to express their views. After the army had charged Presbyterians with intolerance in their unwillingness to afford latitude to dissenters, Wallis was one of fifty-eight London ministers, including Thomas Gataker, Henry Roborough,

25 Twigg: History of Queens' College, pp. 57-858, 62; Hetherington: History of the Westminster Assembly, 3067307.

26 Scriba: »Autobiography of John Wallis«, p. 31; Searle: History of the Queens' College, II, p. 550.

27 Scriba: »Autobiography of John Wallis«, pp. 39-40; John Wallis: A Defence of the Royal Society, and the Philosophical Transactions, particularly those of July, 1670. In answer-Answer to the cavils-Cavils of Dr. William Holder, London 1678, p. 7. Other members of the Royal Society argued that the institution had been founded later in Oxford. On the dispute over origins see Mordechai Feingold: »The Origins of the Royal Society Revisited «, in: Margarete Pelling/Scott Mandelbrote (eds.): The Practice of Reform in Health, Medicine, and Science, 1500-2000, Aldershot/Burlington 2005, pp. 167-83183; Philip Beeley: »Eine Geschichte zweier Städte. Der Streit über die wahren Ursprünge der Royal Society«, in: Acta Historica Leopoldina 49 (2008), pp. 135-62162.

28 House of Commons Journal 5, 146 (20 April 1647); Journal of the House of Lords 9, 148 (22 April 1647).

29 Carlson: »History of the Presbyterian Party«, p. 84. 
and Christopher Love, who issued the pamphlet A Serious and Faithfull Representation from their meeting-place at Sion College on 20 January 1649 (see $\underline{\text { Figure 2 }}$ ) ${ }^{30}$ In so doing, Wallis put his name to a powerful denunciation of the army for subverting the laws of the kingdom, not only through the purging of parliament and the subsequent illegal occupation of the city of London, but also through the trial and impending execution of Charles I. A week later, Wallis was again one of the signatories to the pamphlet $A$ Vindication of the Ministers of the Gospel in, and about London, in which Presbyterians rejected the suggestion in the army pamphlet Agreement of the People that freedom rather than coercion should - of course with the exception of Roman Catholics and Episcopalians - form the basis of religious affairs. ${ }^{31}$

Fig. 2: Title-page of A Serious and Faithfull Representation of the Judgements of the Ministers of the Gospell within the Province of London, London 1649, to which Wallis appended his signature.

It has always been something of a mystery that Wallis in the midst of all the political upheaval surrounding the trial and execution of the king and the proclamation of the Republic was effectively removed to Oxford, where, given the choice of either of the Savilian mathematical chairs, chose the professorship in geometry on 21 June 1649. For Thomas Hobbes, who like his friends John Aubrey and Robert Hooke, never missed any opportunity to attack Wallis for his lowly social status and his supposed inclination to make use of the intellectual property of others, there could be no doubt that this must have been a reward for dishonourable acts. In his Examinatio et emendatio mathematicae hodiernae, published soon after the Restoration in 1660, Hobbes draws his readers' attention to the collection of letters which Wallis had deciphered during the Civil Wars and later, toward the end of the Commonwealth in 1653, deposited in the Bodleian Library in Oxford. ${ }^{32}$ The following year, in 1661, Hobbes used the

30 The full title of the pamphlet is A Serious and Faithfull Representation of the Judgements of Ministers of the Gospell within the Province of London. Contained in a Letter from them to the Generall and his Councell of Warre, London 1649. See Carlson: »History of the Presbyterian Party«, pp. 91, 101; Liu: Discord in Zion, p. 55.

31 The full title of the pamphlet is A Vindication of the Ministers of the Gospel in, and about London, from the unjust Aspersions east Cast upon their former Actings for the Parliament, as if they had promoted the bringin of the King to Capitall punishmentPunishment, London 1648. See Carlson: »History of the Presbyterian Party \&, p. 102.

32 Thomas Hobbes: Examinatio et emendatio mathematicae hodiernae, London 1660, p. 55: »Qua scribendi ratione tempore belli civilis, cum omnes fere uterentur, non pauca hujusmodi scripta in itinere suo (nota quod in Anglia itinera faciunt Epistolae) intercepta ipsi (ut ait) explicanda tradebantur. Et quidem eorum nonnulla tam insuperabili difficultate involuta videbantur, ut fere de illorum explicatione desperaverit, nec nisi post diuturnam inquisitionem incredibili labore superaverit. Quorum non pauca specimina in publica Bibliotheca Bodleyana Oxoniae conservanda tradidit. See also id.: Dialogus physicus de natura aeris, London 1661, p. 35: »Its tamen fuit [sc. Wallisius] ingeniosus, ut Epistolas 
medium of his Dialogus physicus, sive de natura aeris to accuse Wallis of having deciphered the King's cabinet, famously captured at the Battle of Naseby in 1645. Of all the accusations levelled against Wallis by his opponents this was potentially the most dangerous in the context of the restored monarchy. And it is an accusation which has clung to him up to this day because historians have failed to take account of all the available resources. Moreover, it is an accusation which Wallis throughout his lifetime could not have refuted without incriminating himself. He did no more than simply deny it.

\section{Parliament and the Gathering of Intelligence}

Throughout the Civil Wars, during the Commonwealth, and the Protectorate, political and military intelligence played an important role in determining the course of events. From 1642 onwards the House of Commons Journal is full of reports of intercepted letters. Scarce a day passes in the Journal without mention of suspicious missives from abroad, discovered at ports or otherwise, many of which were at least partly written in cipher. In the absence of an official post of decipherer, intercepted letters were often referred to specially appointed committees, such as the Committee for Infomations or the Committee for the Uncyphering of Cyphers. Up to 1646, Sir Walter Earle (or Erle) is named as being at least a member, more usually as being the chairman of the committee. Indeed, on many occasions letters in cipher were handed directly to Earle, who is then usually credited with the deciphering. But Earle was not alone in possessing this skill. When, at the beginning of 1646, letters from Queen Henrietta Maria and the royalist commander George Goring were intercepted at Dartmouth, he was instructed by parliament »to confer with Mr. Wackerlyn and Mr. Frost, for the deciphering them «. ${ }^{33}$

missas a Rege (aliisque, qui bello civili a Rege stabant) scriptas scriptura occulta, sed interceptas, interpretatas sit sive (ut loquuntur) Decyphraverit. «David Underdown: Royalist Conspiracy in England 1649-1660, New Haven 1960, p. 21, writes that Wallis »created something of a stir by deciphering the King's papers after Naseby«, but tellingly produces no evidence for this claim.

33 House of Commons Journal 4, 429 (4 February 1645/646): »Ordered, \&c. That the Letters in Cyphers be referred to Sir Walter Erle and Sir Henry Mildmay; to confer with Mr. Wackerlyn and Mr. Frost, for the uncyphering them; and to bring them in again to the House, on Saturday Morning next.« 
Walter (or Gualter) Frost, a former manciple of Emmanuel College, who later became a political agent, had been appointed co-secretary of the Committee for Both Kingdoms in 1644. ${ }^{34}$ He moved with that committee to Derby House in 1647-8/48 and became secretary to the newlycreated Council of State after the establishment of the Commonwealth in 1649. It is probable that he enjoyed patronage from Robert Greville, and later from Robert Rich and William Fiennes, all of whom had Cambridge connections. Georg Rudolph Weckherlin's background could scarcely have been more different. A protestant emigré from the German state of Württemberg, who was well acquainted with Haak, Samuel Hartlib, and Joachim Hübner, he is reported as having received letters for deciphering on numerous occasions directly from parliament. ${ }^{35}$ Furthermore, there is clear evidence that Weckherlin himself was directly involved both in coding and in decoding of correspondence. ${ }^{36}$ As secretary for foreign affairs to the Committee for both Kingdoms, a post he held from 1644 , he would also have overseen such activities. ${ }^{37}$ It was precisely to this committee that the House of Commons, on 23 June 1645, referred the letters and papers taken at Naseby. ${ }^{38}$ We can therefore assume that those parts of the King's cabinet written in cipher would, as on similar occasions, have been deciphered by or under the supervision of Weckherlin. Just three weeks later, on 14 July 1645, the certified results were published by special order of parliament as The Kings Cabinet Opened, and considerably harmed Charles I's

34 Kew, The National Archives, SP 21/7/1; Jason Peacey: Politicians and Pamphleteers. Propaganda during the English Civil Wars and Interregnum, Aldershot/Burlington 2004, p. 105; Gerald E. Aylmer: The State's Servants: the Civil Service of the English Republic 1649-1660, London/Boston 1973, p. 19.

35 Leonard Forster: »G. R. Weckherlin in England «, in: German Life and Letters (1939), pp. 107-16116, 114; idl: Georg Rudolf Weckherlin. Zur Kenntnis seines Lebens in England, Basel 1944, p. 120; Pamela R. Barnett: Theodore Haak, F. R. S. (1605-1690). The first German translator-Translator of Paradise Lost, The Hague 1962 , pp. $28,52,77$.

36 See House of Commons Journal 4, 422 (30 January 1645/6): »Ordered, That the intercepted Letters, in Cypher, this Day presented to the House by Mr. Speaker, be referred to Mr.Wakerlyn, to be decyphered, if [they] may be.«; ibid., 447 (18 February 1645/6): »A Copy of a Letter, from Culpeper to Ashbournham, dated Tavestock, 12 Januarii 1645, intercepted, and uncyphered by Mr. Weckerlyn, together with the Original of the said Letter, were this Day presented to the House by Sir Henry Heyman: And the Copy was read.«; Proceedings of the Committee of Both Kingdoms, 19 February 1644, Kew, the National Archives, SP 21/7/3: »That a letter be written to my Lo: Fairfax to settle a way to send thence by land to the Scottish Army the Easterne way if it may be done safely. And Mr Weckerlin to prepare a cipher.«; Proceedings of the Committee of Both Kingdoms, 23 February 1644, Kew, The National Archives, SP 21/7/6: »That Mr Weckerlin doe open a pacquett of Letters (which was brought in by Sir Henry Vane; which he procured from Mr Corbett being intercepted comeing from beyond Seas) and to report the Contents to this Committee «; Note on letter of Committee of Both Kingdoms to Ferdinando Fairfax, 1 April 1644, Kew, The National Archives, SP 21/18/42: »This letter put into Cypher by Mr Weckherlyn «. See also Weckherlin's list of intercepted letters, Kew, The National Archives, SP 16/513/50.

37 Peacey: Politicians and Pamphleteers, p. 226; Forster: »Weckherlin in England«, p. 112.

38 House of Commons Journal 4, 183 (23 June 1645): »Resolved, \&c. That the several Letters and Papers taken at Naseby-Field, and sent up by Sir Thomas Fairefax, shall be referred to the Committee; to translate the French Letters, decypher those that are not decyphered, and to sort them.« 
public standing, by revealing that he was prepared to allow an Irish army into England in order to secure certain rights for the Roman Catholic population. ${ }^{39}$ For Weckherlin at that time things could hardly have gone better. In 1647, on account of his services to parliament, he was appointed secretary for foreign languages to the Committee. But political radicalization brought with it at least a temporary halt to his career. In earlier years, Weckherlin had enjoyed close informal contact to Charles I, had travelled with him and had assisted in writing poetry. Soon after the King's execution in 1649 , Weckherlin resigned from his post, no doubt in reflection of his earlier close ties to the monarch. ${ }^{40}$

A good understanding of the balance of power in England in 1645 and of parliamentary records allows us to recognize the absence of any foundation for the claim that Wallis while being employed by parliament contributed to the downfall of Charles $I .{ }^{41}$ Not for the first time, Hobbes quite simply got his facts wrong. As if this were not bad enough, Hobbes's mistake has effectively served to divert attention from the true nature of Wallis's deciphering work which in many ways had more momentous consequences. Moreover, it is only against the background of his historically verifiable work as a code-breaker that a decisive stage in his biography begins to make sense: his appointment as Savilian professor in June 1649.

\section{The Presbyterian Conspiracy 1649-1651}

If Pride's Purge sought to curb political instability in England it failed miserably. Even outside parliament Presbyterians remained inflexible in their opposition to religious tolerance; political and religious dissent in the country increased, while almost daily new reports of problems in Ireland reached the capital. To a certain degree the government responded by adopting a more

39 The Naseby letters, deciphered and transcribed, were published by order of parliament in the same year: The Kings Cabinet opened: Or, certain packets of secret letters \& papers, written with the Kings own Hand, and taken in his Cabinet at Nasby-Field, June 14. 1645. [...] Wherein many mysteries of State, tending to the Justification of that Cause, for which Sir Thomas Fairfax joyned battell that memorable day are clearly laid open, London 1645.

40 Barnett: Theodore Haak, p. 94; Forster: »Weckherlin in England«, p. 110; id.: »Georg Rudolf Weckherlin«, pp. 98-101, 121.

41 John Davys: An Essay on the Art of Decyphering. In which is inserted a Discourse by Dr. Wallis. Now first publish'd from his Original Manuscript in the Publick Library at Oxford, London 1737, pp. 6-7, points to the lack of any evidence that Wallis participated in the decoding of the King's cabinet. Moroever, he finds it unlikely that the cabinet would not have contained the deciphering keys alongside the ciphers themselves. See Marshall: Intelligence and Espionage, p. 93; Underdown: Royalist Conspiracy, pp. 295-6296. 
conciliatory attitude toward Presbyterians, but this did little to calm their anger. While some agitated publicly against the Commonwealth, others began secret negotiations with the exiled king and representatives of the Scots which soon developed into a full-blown conspiracy lasting from 1649 to 1651 . Those involved had the broad aim of restoring Charles II to the English thrown under recognition of the Solemn League. ${ }^{42}$ Within a short time it embraced a considerable number of influential citizens and London ministers together with a group of military officers who had become disaffected by political developments. The most active member was the London mercer William Drake, but equally notable were Presbyterian leaders at the exiled royal court in Holland: Francis Lord Willoughby, Major-General Edward Massey, Colonel Robert Graves, and Alderman James Bunce, the principal initiator of the conspiracy since late $1648^{43}$. It was Massey, Graves, and Bunce, together with Captain Silas Titus, a fellowconspirator from the beginning, who represented the English Presbyterians at talks with the Scottish commissioners and the king, leading to the Treaty of Breda of 1 May $1650 .{ }^{44}$

Part of the reason for the rapid emergence of the plot following the proclamation of the Republic was the concern, expressed particularly by Titus, that Charles II might otherwise be persuaded to join forces with the Irish Catholics. Evidence reveals that Titus journeyed to London from his Dutch exile to meet with the group of Presbyterians around Drake in February 1649 , and that the conspirators possessed a concrete agenda and plans already in March and April of that year. Since their aims were treasonable, deliberations were conducted in the utmost secrecy, while correspondence was conducted in cipher and without the use of signatures. ${ }^{45}$ Moreover, many incriminatory documents were deliberately destroyed after having been read so as not to fall in the wrong hands. Not without reason, the government sought to keep abreast of such dangers to its very existence by means of a sophisticated intelligence network with agents and spies operating both at home and at foreign courts, particularly among exiles. Already toward the end of the Long Parliament the man who took on a central part in these efforts was

42 Carlson: »History of the Presbyterian Party«, pp. 108-9109.

43 See the Richard Watson's letter to William Edgman, sent from Breda on 7 September 1649, in: State Papers collected by Edward, Earl of Clarendon, ed. Richard Scope and Thomas Monkhouse, 3 vols., Oxford 1767861786, vol. II, p. 491: »I was lately, you would little think it, the only man invited to a Captain's chamber dt dinner; where I met Massie, Graves, the King's jailor at Holmby, Alderman Bruce of London [...] The Captain who invited us, was a very Presbyterian too. «See also Carlson: »History of the Presbyterian Party«, p. 110.

44 George Hillier: A Narrative of the Attempted Escapes of Charles the First from Carisbrook Castle, London 1852, p. vi; Carlson: »History of the Presbyterian Party«, p. 115.

45 Carlson: »History of the Presbyterian Party«, p. 117. 
the Buckinghamshire attorney, Thomas Scot, who had won election to parliament as an Independent. Although his role was only formalized in July 1649, when the Council of State appointed him »to manage the businesse of Intelligence both at home and abroad for the service of the state«, he is repeatedly cited in the House of Commons Journal from the summer of 1648 onward as being the chairman of the committee responsible for deciphering at Derby House, the Committee for Safety. ${ }^{46}$ Historical records show that the Presbyterian plot was eventually foiled when one of the conspirators, Major Thomas Adams, was discovered by the government agent Major John Cobbett. Adams subsequently agreed to cooperate with Scot and the information he provided led to the arrest of the royalist agent Thomas Coke together with Isaac Birkenhead. Other arrests soon followed, including a large number of Presbyterian ministers. ${ }^{47}$ Of Wallis's fellow signatories to the Serious and Faithfull Representation and A Vindication of the Ministers of the Gospel, eleven were behind bars by the middle of June 1651. Another signatory, Christopher Love, one of the most zealous conspirators, was executed. ${ }^{48}$ Scot, whose loyal service to the Commonwealth was paired with utter rejection of the Protectorate, was made a member of the intelligence committee following the reinstatement of the Rump Parliament in 1659, and the served for a short period as successor to John Thurloe as secretary of state at the beginning of the following year. However, he was forced to flee the country when it became known that he had given support to Ludlow's efforts to prevent the restoration of Charles II. After his surrender in Brussels and his return to England, Scot gave an account of his work as an intelligencer, apparently in the hope that his impending death sentence as a regicide might be commuted. His testimony is particularly remarkable, because it shows the central importance which Wallis's work as a decipherer played in revealing the activities of Presbyterian conspirators over the years. And it is remarkable, too, because Scot does his utmost to portray

46 Kew, The National Archives, SP 25/62/484. See also Aylmer: The State's Servants, pp. 19, 21, 53.

47 Some light is thrown on the arrests in Francis Johnson's letter to the Marquis of Ormonde, sent from the Hague on 14/24 May 1651, in: Thomas Carte (ed.): A Collection of Original Letters and Papers, concerning the affairs Affairs of England, from the year Year 1641 to 1660. Found among the Duke of Ormonde's papers Papers, 2 vols., London 1739, vol. II, p. 3: »We hear by several letters from England, that shortly after Titus's papers were brought to the council of state, divers Presbyterians as well as Cavaliers in the West were imprisoned, and fifteen Presbyterian Ministers; which is said to be done upon a list of names which Mr. Secretary Hollis gave to Titus.«

48 A detailed account of the background to the trial and execution of Love is given by Blair Worden: The Rump Parliament 1648-1653, Cambridge 1974, 243-8248. See also Carlson: »History of the Presbyterian Party«, pp. 113, 121; Underdown: Royalist Conspiracy, p. 49.
Kommentiert [PS36]: Mit e am Ende? 
Wallis as a disinterested code-breaker, whose skills would benefit any future ruler who recognized the importance of political intelligence, a »jewell for a Princes use«, as he calls it.

»The Kings transactions with the Presbyterean Ministers here, in \& about London, by their Commissioners at Breda, I meane Lord Willoughby, Coll. Graves, Alderman Bunce etc. were made knowne to mee first by one Mr Harvy, since dead, and after by Major Adams who kept them daily Company here, but very much more by letters intercepted which commonly were every word \& syllable in Cypher, and decyphered by a learned gentleman incomparably able that way, Doctor Wallis of Oxford (who never concerned himself in the matter, but only in the art \& ingenuity); it is a jewell for a Princes use $\&$ service in that kind. $\ll^{49}$

This assessment of his role would ultimately be of tragic consequence for Wallis. When it came to deciphering, he was not the learned member of the Republic of Letters, nor was he the respected officer of the University of Oxford, but quite simply the servant of powerful men in high places. And as a servant he did not have the benefit of choice, rather, he had to do what he was instructed.

\section{Code Breaking and Academic Preferment}

Wallis's name is not mentioned in any of the parliamentary journals of the time, but perhaps this is not surprising. He would not have been employed in an official capacity, nor would he have been a member of an influential parliamentary committee such as the Committee for Safety. On the other hand, we do not know to what extent men who are named, such as Frost and Weckherlin, were actually involved in code-breaking as opposed to deciphering using known keys. Scot's exclusive reference to Wallis and the praise it contains suggests strongly that he was the regicide's principal, if not only code-breaker, at least with regard to the Presbyterian plot. Given the emergence of that plot early in 1649 , it seems very probable that Scot and other members of the Rump recognized the need to remove Wallis from the potentially conflicting interests to which he would have been exposed in the community of other Presbyterian ministers in London, many of which he would have met on a regular basis in and around Sion College. At

49 Charles Harding Firth: »Thomas Scot's Account of his Actions as Intelligencer during the Commonwealth «, in : English Historical Review 12 (1897), pp. 116-126, 121. See also Philip Aubrey: Mr Secretary Thurloe: Cromwell's Secretary of State 1652-1660, London 1990, p. 28; Peacey: Politicians and Pamphleteers, pp. 226-7227; Underdown: Royalist Conspiracy, 21, pp. 295-6296; Worden: The Rump Parliament, p. 243. 
the same time, his intimate knowledge of that community would have been a clear benefit to him in view of the exclusive use of ciphers in correspondence. Despite his moderate Presbyterianism, he evidently subsumed religious convictions under demands of loyalty to the state. For his service and dedication a suitable reward would need to have been forthcoming and a Savilian professorship was in many ways an obvious proposition.

The incumbent professors of astronomy and geometry, John Greaves and Peter Turner, had been ejected from their posts on 20 October 1648 on instruction of the Committee for Regulating the University of Oxford. ${ }^{50}$ Both posts had since remained vacant. Wallis had indicated his keenness in pursuing a university career through his acceptance of the fellowship at Queens' College five years earlier. Being married, he was no longer eligible for a fellowship and in any case his intellectual interests were now decidedly mathematical. Not long after his exchanges on cubic equations with John Smith in late 1648, he was shown a copy of Johannes Hevelius's Selenographia by Samuel Hartlib. He immediately wrote to the astronomer, encouraging him to proceed further in his mathematical studies and regretting that his own work was not worth mentioning, since he had to devote his time to theological work in order to earn his living. ${ }^{51}$ Through his industry as a decipherer and with parliament's help he would however soon be able find a means to change that.

Once established in post, Wallis made no attempt to conceal his code-breaking activities. However, in an astute move, rather than promoting himself directly, he allowed another to do this for him. When William Oughtred, universally revered among England's small but growing mathematical community, published the third edition of his Clavis mathematicae denuo limitata, he used the preface to extol Wallis's skill »in unravelling and explicating secret writing hidden behind the most intricate ciphers « alongside praising him for his perspicuity in mathematical matters themselves. ${ }^{52}$ Since Wallis was closely involved in producing that edition, as Oughtred gratefully acknowledges, we can be sure that this was publicity which he sought to receive. This

50 Montagu Burrows: The Register of the Visitors of the University of Oxford from A. D. 1647 to A. D. 1658 (= Camden Society New Series 29), London 1881, pp. 200, 282-3283.

51 Wallis to Hevelius, 3/[13] April 1649, Correspondence of John Wallis, vol. I, pp. 10-11.

52 William Oughtred: Clavis mathematicae denuo limata, sive potius fabricata, Oxford 1652, sig. A5 ${ }^{\mathrm{v}}$ : »[...] debetur Venerablilis Viri Dn. Joannis Wallis [...] Viri ingenui, pii, industrii, in omni reconditiore literatura versatissimi, in rebus Mathematicis admodum perspicacis, \& in enodatione explicationeque Scriptorum intricatissimis Zepherarum involucris occultatorum (quod ingenii subtilissimi argumentum est) ad miraculum faelicis. « 
was just a foretaste of what was to come. During the following year, which politically could scarcely have been more turbulent than it was - the Rump was followed in July by the Barebones Parliament and finally in December the Protectorate was established - Wallis carefully prepared what he called »A Collection of Letters and other Papers, which were at severall times intercepted, written in Cipher, Deciphered « and presented it to the Bodleian Library. The collection comprises fifty-two cipher letters in total, together with their respective keys and plain-text solutions, and beginning with the letter which Wallis fatefully deciphered after dinner at Lady Vere's London residence. The Windebank letter, and its solution, is also included, but most of the ciphers date from 1650 and draw their context from the Treaty of Breda. Evidently, it was the science of deciphering and Wallis's excellence at this science, rather than political intrigue which was to be documented in this collection. None of the Presbyterian conspirators is mentioned, except Silas Titus, who had switched his support to the royalist side in 1651, and was evidently in a safe enough position at the time..$^{53}$ In the preface to his collection, with not a little pride, Wallis speaks of the importance of secret intelligence to the conducting of political affairs:

»It is not unknown, to those who know anything of publike affairs, of how great concernment it is, especially in civill commotions, for those who are to manage such transactions, to be furnished with continuall intelligence from their Correspondents, yet so as to conceal their counsells \& resolutions from the adverse party. $\aleph^{54}$

But what is perhaps most remarkable about the collection is that to all intents and purposes it is a book, neatly bound, complete with title-page, preface, and index (see $\underline{\text { Figure } 3}$ ). As such it bears evident similarity to the collection of deciphered letters which Wallis produced in the final days of his life. Had he tried unsuccessfully to find a publisher in 1653 or was the »Collection of Letters and other Papers « simply to be left in such a form that it might be admired by readers to the Bodleian Library or perhaps even published at a later date? We simply do not know. In many ways the background to the collection is as opaque as that of his Grammatica linguae

53 After the Restoration, Titus became engaged in political affairs, and Wallis describes him as being »very well accomplished in Mathematical and other Learning «. See Wallis: Treatise of Algebra, both Historical and Practical, London 1685, p. 225.

54 Oxford, Bodleian Library, MS e Musaeo 203, vii-viii. 
Anglicanae, which was published by Leonard Lichfield, the printer to the University, in the same year and of which no mention whatsoever is to be found in any of his extant correspondence. ${ }^{55}$

Fig. 3: Title-page of the collection of deciphered letters deposited by Wallis in the Bodleian Library in 1653, Oxford, MS e Musaeo 203, p. v.

\section{The Art of Deciphering and the Republic of Letters}

Despite Oughtred's praise, and even Hobbes's venom, Wallis's exploits as a decipherer failed to achieve the recognition which he evidently so dearly sought. It was as a mathematician, and to a lesser extent as a linguist and theologian, that his name ranked among the most esteemed scholars in the republic of letters. But there was one notable exception among Europe's learned who did not pass over Wallis's exploits in silence and this was Gottfried Wilhelm Leibniz. Recognizing that minds that excel in algebra, »the pinnacle of calculus «, as he calls it, ${ }^{56}$ also excel in deciphering, Leibniz already at the outset of his mathematical career, during his momentous stay in Paris 1672-1676, compares the search for the rule of a series, or of an array or a »table«, with the search for the key of a cipher. After noting that one series might be part of another and that in such cases it is necessary to choose that which is simplest and best accommodates the data, he goes on to describe this as being the doctrine of discovery or hypothesis, »of which no one up to now has dealt with accurately «. ${ }^{57}$ But for at least part of this doctrine, namely that concerning the construction or solving of ciphers, Leibniz makes clear that he already has someone in mind for the job: »I should like this to be accurately dealt with by Wallis «, he writes.

Leibniz remained fascinated by the potential of the art of deciphering throughout his life, both for scientific and political reasons, and particularly in later years often entreated Wallis to

55 John Wallis: Grammatica linguae Anglicanae. Cui praefigitur, de loquela sive sonorum formatione, tractatus grammatico-physicus, Oxford 1653.

56 Leibniz to Schmidt, 10/20 March 1699, in: A I, 16, p. 639: »Nam Algebra est calculi apex.«

57 G. W. Leibniz: De method quadraturarum usu in seriebus, in: A VII, 3, p. 253: »Potest autem eadem series data esse pars aliarum diversarum, ex his eligenda est simplicissima aut rebus praesentibus accommodatissima, quod aliunde dignosci potest. [...] Est haec ipsissima doctrine divinandi seu de hypothesibus, quam nemo accurate tractavit. Huius pars est doctrina de chiffris construendis solvendisque, quern vellem a Wallisio accurate tradi.« 
reveal something of his methods. ${ }^{58} \mathrm{He}$ addressed this topic also in his anonymous review of Wallis's Treatise of Algebra for the Acta eruditorum. Referring to Jacques Auguste de Thou's testimony to François Viète's skill as a decipherer, ${ }^{59}$ Leibniz suggests that Wallis would equal or even surpass the praises poured on the French mathematician if he were to provide posterity with a specimen of his own accomplishments. ${ }^{60}$ Apart from those fortunate enough to visit the Bodleian Library, scholars had nothing else to go on except what Oughtred and Hobbes had written. It would appear that Leibniz at this time based his knowledge exclusively on the short passage in the Examinatio et emendatio mathematicae hodiernae. There, the English philosopher, clearly aware of the rivalry which existed between Wallis and certain French mathematicians, had mentioned De Thou's testimony alongside his remarks on the collection of letters which Wallis had deposited in the Bodleian Library.

In November 1695, Leibniz sent a note to Wallis, enclosed in a letter to Thomas Burnett of Kemney, in which he expressed his interest in the interpolation of number sequences mentioned in the Commercium epistolicum de quaestionibus mathematicis Wallis had published in $1658 .{ }^{61}$ Carried from Hanover by unknown travellers, this epistolary communication took many months to reach its addressee. Wallis replied just over a year later, on 1 December 1696, his letter being the first direct correspondence between the two men. ${ }^{62}$ In the mean time the Savilian professor had heard from Thomas Smith that Leibniz desired that he provide the public with something on

58 See Philip Beeley: »Un de mes amis. On Leibniz's relation-Relation to the English mathematicial Mathematician and theologian-Theologian John Wallis«, in: Pauline Phemister/Stuart C. Brown (eds.): Leibni and the English-Speaking World, Dordrecht 2007, pp. 63-81, especially 68-969, 72-575.

59 Jacob Auguste de Thou: Historiarum sui temporis ab anno Domini 1543 usque ad annum 1607, libri CXXXVIII, 5 vols., Geneva 1620-261626; lib. 129, vol. V, pp. 1060-11061. The corresponding passages werte reprinted in François Viète: Opera mathematica, in unum volumen congesta, ac recognita, ed. Frans van Schooten, Leiden 1646 , sig. $* 44^{\mathrm{r}}-* 5^{\mathrm{r}}$.

60 Gottfried Wilhelm Leibniz, review of John Wallis: A Treatise of Algebra, both Historical and Practical, in: Acta Eruditorum eruditorum VI (1686), pp. 283-9289: „Caeterum cum celeberrimus Autor (quemadmodurp intelleximus) excellat in solvendis, sive, ut vulgo loquuntur, deciphrandis Cryptographematibus, eaque scientia magnam cum illis, quae in hoc opere traduntur, affinitatem habeat, orandus magnopere est, ut praecepta ejus tradat, praesertim cum ea, quae hactenus prostant, valde sunt imperfecta. Ita hoc quoque genere Vietae laudes aequabit, imo vincet, si duraturo ad posteritatem specimine ostendat, quod illum fecisse soli Thuani testimonio credere cogimur. $\ll$

61 Leibniz for Wallis, 6/[16] November 1695, in: A III, 6, pp. 577-8578; Joseph Ehrenfried Hofmann: »Leibnit und Wallis«, in: Studia Leibnitiana 5 (1973), pp. 245-81281, 267.

62 Wallis and Leibniz had corresponded indirectly via Henry Oldenburg in the early $1670 \mathrm{~s}$ on the topic of Leibniz's Hypothesis physica nova which the Savilian professor was asked to review. See Philip Beeley: »A Philosophical Apprenticeship. Leibniz's correspondence with the Secretary of the Royal Society, Henry Oldenburg«, in: Paul Lodge (ed.): Leibniz and his Correspondents, Cambridge 2004, pp. 47-73, especially 5962. 
his method of solving the riddles of secret writing. ${ }^{63}$ Evidently in an attempt to head off too much inquisitiveness from abroad, Wallis decided to send an example of a French substitution cipher with its plain text solution to the editor of the Acta Eruditorumeruditorum, knowing full well the close ties Leibniz had to Mencke. ${ }^{64}$ No doubt suspecting Leibniz's authorship, and with the tactical finesse befitting one who had learnt to deal with government officers, Wallis cited as his grounds for sending the material to Otto Mencke the anonymous review of the Treatise of Algebra which had appeared in the Acta Eruditerum-eruditorum some ten years earlier. ${ }^{65}$ While Wallis's packet was on its long journey to Leipzig, Leibniz let it be known to Thomas Burnett, a mutual friend of both him and Wallis, that he would soon be writing to Savilian professor in order to implore him to supply the public with something on the art of deciphering $\gg$ in which he succeeded marvellously during his youth ${ }^{6}{ }^{6}$

But if Wallis thought he had successfully outmanoeuvred Leibniz, he would be sorely disappointed. Mencke was less than enthusiastic at the sight of the package he received from Oxford, consisting as it did of two folios pages of numerical substitution code, together with the plain text letter, the key, and an intermediate stage with cipher and partly interlined solution. ${ }^{67}$ With good reason, Mencke was concerned that the letter might be politically compromising to those it concerned, but perhaps more pertinently he was unable to discern any scientific value in what Wallis had sent. When he later sent the material on to Leibniz, he suggested that if it had any such value it would surely have been printed beforehand in the Philosophical
Kommentiert [PS37]: Die Schreibweise „Acta eruditorum“ überwiegt, daher habe ich durchgängig eruditorum klein gesetzt.

63 Leibniz to Smith, 6/16 October 1696, in: A I, 13, p. 300: »Cl. Wallisium gaudeo rem adhuc praeclare gerere. Vellem vir egregius aliquid nobis daret de Arte solvendi aenigmata cryptographica, in qua vix quenquam parem sese habere ostendit.«

64 Wallis to Mencke, 1/11 January 1696/797, in: John Wallis: Opera mathematica, 3 vols., Oxford 1693-91699, vol. III, pp. 659-660; the enclosures to the letter are printed 660-7667. At the beginning of the letter, Wallis notes that he does not need to repeat what he has written to Leibniz a month earlier, because he supposes that he and Mencke are in regular correspondence.

65 Wallis claims that he only stumbled on the review of the Treatise of Algebra after he had written to Leibniz: $»$ Post eas [sc. literas] missas; incidebam nuper in Acta Lipsica pro mense Junii 1686.« (p. 659).

66 Leibniz to Burnett, 1/11 February 1697, in: A I, 13, p. 551: »Mons. Wallis a aussi recue le sien [sc. billet], et m'a écrit une ample et sçavante lettre à cette occasion. Je luy repondray bien tost, et l'exhorteray de nous donner quelque chose sur l'art de dechiffrer, où il reussissoit merveilleusement dans sa jeunesse. Il feroit bien d'enrichir le public de ses pensées sur cette matiere.«

67 The letter concerned, on the election of a new pope following the death of Innocent XI, was from the French emissary to Poland, François-Gaston de Béthune to Louis XIV's special envoy to Rome, Cardinal César d'Estrées and was dated 6 September 1689 (new style). The original manuscripts are now Hanover, Gottfried Wilhelm Leibniz Bibliothek, LBr 974, Bl. 8-13. 
Transactions. ${ }^{68}$ It was of course quite different from the kind of answer Leibniz hoped to receive from Wallis. He was also not convinced that the code could have been broken on the basis of single letter. ${ }^{69}$

Wallis's first genuine attempt at publishing an example of his code-breaking ability was an unmitigated failure. Mencke, whose curiosity (and at the same time that of Leibniz) Wallis had hoped to satisfy passed over his contribution in silence. However, as we know from his long lasting intellectual war with Hobbes, the Savilian professor was not easily defeated. Just two years later, the cipher and its solution did appear in print: Wallis published it as part of the collection of scientific correspondence contained in the third volume of his monumental Opera mathematica (1693-99-1699) (see Figures 4 and 5). By also including there his letter to Mencke, Wallis sought to convey the impression that he had indeed fulfilled his scientific obligation to the Republic of Letters despite the decision of the editor of the Acta eruditorum not to allow his journal to be employed for this purpose.

Fig. 4: Part of the ciphered letter from the French envoy to Poland, the marquis F. de Béthune to Cardinal César d'Estrées, dated 6 September 1689 (new style), with plain text interlined, published by Wallis in his Opera mathematica III, p. 663.

Fig. 5: Part of key to aforementioned letter, published by Wallis in his Opera mathematica III, p. 666.

As Leibniz had already indicated to Burnett, he used the opportunity of his reply to Wallis to impress upon the Savilian professor the need that he publish something about the art of »divining that which is secretly written «.70 Yet again the review of the Treatise of Algebra was brought into play: Leibniz pretended that the anonymous author of that review was another voice in the Republic of Letters calling for Wallis to reveal more about his cryptographic practice. This ploy was unlikely to have impressed Wallis, but in any case, like most other cryptographers before and after him, he was not inclined to give away any secrets as far as his own methods were concerned. In his reply he simply pointed out that the art of deciphering could not be reduced to certain rules »on account of the infinite variety of ways in which ciphers can be applied « and

68 Mencke to Leibniz, 22 May/[1 June] 1697, in: A I, 14, p. 245: »Ich sehe auch nicht, cui bono; sonst würde Ers wol in die Transact. gegeben haben."

69 Leibniz to Mencke, August-beginning of September 1697, in: Hbidibid., p. 439: »Es ware zu wündschen daß H. Wallisius nicht nur solutionem Epistolae cryptographicae, sondern auch modum solvendi geben hätte. Ich glaube aber daß era us diesen einzigen brief clavem also wie er sie hier gegeben nicht finden können.«

70 Leibniz to Wallis, 19/29 March 1697, in: A III, 7, p. 353: »[...] ut de Arte Divinandi occulte scripta.« 
because of their difficulty »which is already great and grows from day to day ${ }_{.7}^{71}$ Nonetheless, in an effort to satisfy Leibniz's curiosity he does make some general remarks on his approach, but these do not go beyond the obvious, or indeed what he had already mentioned in his letter to Mencke: the need to start with conjectures and then proceed according to whether they prove to be successful or not. He also mentions to Leibniz that he has sent an example of a cipher with its solution to the editor of the Acta eruditorum, evidently hoping in this way to bring discussion on this troublesome matter to a close. Wallis was happy to be admired, but he did not want to permit the source of that admiration to be undermined.

Wallis was quite evidently torn between two opposing and indeed irreconcilable forces. On the one side he sought acclaim within the Republic of Letters as one who was able to break even the most difficult codes. His various efforts to provide some sort of documentation of the deciphering work he had done are a clear reflection of this aspiration. On the other side he recognized that if were too forthcoming he would severely compromise himself as well as those who employed him.

Anything more than the visible display of his achievements $s$ would have necessitated providing insight into the precise nature of the methods and strategies he employed. To have done this would have meant not only potentially destroying the uniqueness of his skill and therefore also undermining what was hitherto considered to be an unassailable if informal position in the apparatus of state, it would also have given those who devised the codes over which he toiled, and more often than not succeeded in breaking, precisely the kind of information they sought. The structures of political intelligence were not only concerned with concealment of information, but also with discovering just how much the other side was capable of finding out and if necessary modifying the code so as to make it even more impenetrable. On more than one occasion Wallis complained to secretary of state Daniel Finch, second earl of Nottingham, that the French »change their Ciphers often«. He even suggested that they »study

71 Wallis to Leibniz, 6/[16] April 1697, in: Hbidibid., p. 375: »Quod memoras de Arte divinandi Occulte scripta: est ea res non certis regulis coercenda propter infinitam varietatem Ciphras ponendi, (et quarum difficultas, jam satis ardua, quotidie crescit,) quae a conjecturis principio positis inchoanda est; quae prout succedere vel non succedere deprehenduntur, vel prosequendae sunt vel mutandae, donec quod certi constat.« 
every time to make them harder then before $\ll{ }^{72}$ Wallis's indispensability, his status, and his reputation inevitably rested on the inscrutability of his methods.

\section{Princes, Courtiers, and False Promises}

While Wallis sought recognition and admiration for his code-breaking endeavours from other members of the learned world, both at home and abroad, he generally received little more than words of praise and the occasional royal payment procured by those in government office who employed him. Precisely because deciphering was seen as a form of employment, interests were involved: the interest of the state and its allies on the one side to gain access to encoded intelligence and the interest of the decipherer on the other side to be commensurately rewarded. The decisive word here is commensurate: Wallis expected more than he was given or than he was led to believe he would be given by those who made use of his services. Having been rewarded for his work for parliament in the 1640s by academic preferment, he no doubt felt that a similar kind of reward would be appropriate for his extensive deciphering forty years later, particularly since he would soon become aware of the considerable consequence of his labours.

When William III came to the thrown in 1689 , he brought with him a deep awareness of the importance of surveillance and intelligence in framing policy, not only against the background of what became known in England as the War of the Great Alliance, but also in respect of political and military developments in Ireland. Wallis played a crucial role in these intelligence-gathering operations. Despite his advancing years, he received and deciphered literally hundred sheets of highly complex, mainly French cipher to work on between 1689 and 1692 alone. This was an impressive achievement, effectively matching the capability of his counterpart. The great French cryptographer Rossignol had established a strong tradition in numerical substitution codes, and French ciphers were generally considered to be the most secure in Europe. ${ }^{73}$ This intelligence

72 Wallis to Finch, 9/[19] November 1689; London, British Library, Add. MS 32499, f. $81^{\mathrm{v}}$. See also Wallis to Finch 4/[14] August 1689, ibid, f. 45 ; Wallis to Finch, 5/[15] October 1689, ibid., f. 86 ; Wallis to Finch, 5/[15] November 1689, Kew, The National Archives, SP 32/2, No. 46. Wallis also notes the increasing complexity of French ciphers in his autobiographical notes. See Scriba: »Autobiography of John Wallis«, p. 38: »But of late years, the French Methods of Cipher are grown so intricate beyond what it was wont to be, that I have failed of many; tho' I have master'd divers of them.

73 Pesic: »Secrets, Symbols, and Systems«, p. 685; Kahn: The Code-Breakers, pp. 157-8158. 
capability was a powerful tool in Louis XIV's armoury when planning and carrying out his military campaigns.

One of William III's most strategically important allies in addressing the French foreign policy was Brandenburg-Prussia, which in contrast to most other German states had no black chambers of its own. It was therefore of mutual interest both to the Elector of Brandenburg, Frederick III, and to the English crown that intercepted or otherwise procured letters in cipher, originating from the French court or from Louis XIV's army commanders, agents or ambassadors be deciphered in England. The principal and probably sole code-breaker was the Savilian professor of geometry at Oxford. Although ostensibly a disinterested party in the affairs with which he dealt, Wallis could claim as his most considerable success the timely discovery of a French plan, in 1689, to persuade the Polish king, Jan III Sobieski, to attack Brandenburg and regain what Poland regarded as its rightful territory. The details of the uncovered plan, conveyed from London to Warsaw, led to a diplomatic scandal: the emissaries who had been sent to carry out the secret diplomatic mission were thrown out of Poland, effectively thwarting French intentions in Brandenburg-Prussia at that time. ${ }^{74}$ It was of course advantageous in this instance that there would be no personal or political implications political closer to home. Wallis could talk quite openly in his correspondence with government officers without fear of repercussions.

The letters which Wallis exchanged with secretary of state Nottingham during his work on the latest French cipher are revealing. They show Wallis at first concerned to convey the impression of a conscientious and hardworking public servant who set about the task of deciphering immediately on receipt of the intercepted document: »from the time your servant brought me the Letter yesterday morning, I spent the whole day upon it (scarce giving my self time to eat). ${ }^{75}$ In another letter, written not long afterwards, he continues to create the same impression, saying that he is »allmost ashamed « to tell his lordship »how much time \& pains \& study I have employed on that very perplex cypher in the Letter from Poland, \& have not yet dispatched it. $\ll^{76}$ But now he also takes the opportunity to provide initial insight into the content of the ciphers, saying that he has disclosed two things which seem to him to be of importance,

Lucien Bély: Les secrets de Louis XIV. Mystères d'État et pouvoir absolu, Paris 2013, p. 241.

75 Wallis to Finch, 4/[14] August 1689, London, British Library Add. MS 32499, f. 45v

76 Wallis to Finch, 18/[28] August 1689, London, British Library Add. MS 32499, f. 55v; David E. Smith: »John Wallis as eryptographerCryptographer«, in: Bulletin of the American Mathematical Society 24 (1917), pp. 82$96,87$. 
»One is a Treaty (or intreaty rather) of the French King with the King of Poland presently to make war on Prussia.« This, he suggests, was to give Emperor a free hand, while the other topic of importance was about »a marriage of the Princess of Hanover with the Prince of Poland«, which marriage the Louis XIV was actively promoting. Wallis continues to portray himself as the dutiful employee of the state, concerned that what is likely to be important information is passed on in a timely fashion. He explicitly denies, if perhaps rather disingenuously, that he has any right to form a judgement on significance of what has been made manifest:

How far it may be of concernment to us to know, I am no competent Judge; But I thought it did become me to give this timely notice of it (lest there might be a prejudice by delay) while I am preparing to give a fuller account of that letter. ${ }^{77}$

By providing his employer an explicit account of the time and effort he was expending on the ciphers, and by showing his concern for that the interests of state should be protected, Wallis sought to demonstrate that he was worthy of the kind of preferment and social elevation he was hoping to achieve. But crucially he did not succeed in liberating himself from the role of public servant which the earl of Nottingham was all too happy to perpetuate. Thus, when Wallis writes to him in September, thanking him for a gift of fifty pounds for his services, he also indicates his keenness to receive similar ciphers in the future, precisely in the manner that a willing servant would do.

The turning point in the relationship between the two men appears to have been when the expectations of the one and the behaviour of the other could no longer be brought into alignment. During a visit to London in February the following year, nearly four months after he had revealed the content of the French cipher concerning the king of Poland, Wallis was asked to meet with Nottingham at his residence in Berkshire House and at his office in Whitehall. On neither occasion did Nottingham take the trouble to appear or to send a timely message excusing his absence, so that Wallis was left waiting to no avail. To make matters worse, a friend reported to him that he had overheard someone mention at dinner that the Elector of Brandenburg had sent the Savilian professor a large gold medal and chain of gold as a token of appreciation for his

77 Wallis to Finch, 18/[28] August 1689, London, British Library Add. MS 32499, f. 55 ; Smith: »John Wallis as eryptographerCryptographer «, p. 87; Kahn, The Code-Breakers, pp. 167-8 $\underline{168 .}$. 
having deciphered the incriminating letters from the French court. In both respects, and not without justification, Wallis felt he had been slighted. When he subsequently took issue with Nottingham over the way in which his name had been disclosed publically in connection with deciphering, he took care to draw attention to the kind of company his friend kept. Not only was the dinner hosted by »a Noble Lord«, and therefore a man of similar standing to Nottingham himself, but also further lords were present as well as »other persons of quality «. ${ }^{78}$ While thus indicating the inappropriateness of the manner Nottingham had treated him by not being present at the appointed time and place to give him his »commands for Oxford«, Wallis also suggests that government officers, by implication the secretary of state himself, had treated important and sensitive matters of state far too freely:

\footnotetext{
"And, why I doubt whether it be advisable to make it so publike (that I decipher the French Kings letters) is, because it can then hardly be avoided but that this will some way or other come to the French Kings knowledge from some of his correspondents here: which will be attended at lest with one or both of these inconveniences, viz: A greater care to prevent the intercepting of such letters; And, a change of the ciphers they now use (which they have already changed more than once). $\ll^{79}$
}

Apart from occasional sums of money, the gold medal and chain was all Wallis would ultimately have to show for his efforts. However, even by June of the following year, he still had not so much as even seen the elector's gift reportedly sent over from Berlin. Had it arrived, he writes to James Johnston, the King's extraordinary envoy and principal commissioner at the Prussian court, »it is like I might have given it to the public library, to be kept among the medals there, as a monument to my services and their gratitude; and therefore I should not myself be much the richer for it « ${ }^{80}$ Johnston had been well informed about the gold medal and chain all along. Indeed, it is highly likely that he conveyed to Berlin the idea of making such a presentation to Wallis in the first place. As we know from his subsequent letter to Nottingham, it was Johnston who made the indiscrete remarks over dinner reported to him by his friend. However, when Wallis after hearing that report met with Johnston, the envoy said nothing whatsoever about a

78 Wallis to Finch, 20 February/[2 March] 1689/90, London, British Library Add. MS 32499, f. 197v Smith: »John Wallis as eryptographerCryptographer«, p. 89.

79 Wallis to Finch, 20 February/[2 March] 1689/90, London, British Library Add. MS 32499, f. 197' Smith: »John Wallis as eryptographerCryptographer«, pp. 89-90.

80 Wallis to Johnston, 9/[19] June 1691, The Gentleman's Magazine 58 (1778), Pt. II, No. 3 (September), pp. $759-60 \underline{760}$. 
gold medal and chain, but only indicated that the elector intended to send him »a mark of his favour $\ll .81$

Wallis's remarks in his letter to Johnston suggest that, like the collection of deciphered letters he deposited in the Bodleian Library and the material he published in the Opera mathematica, he initially considered using the medal and chain to provide a lasting memorial to his work. When the medal eventually did arrive, its poor quality only added to Wallis's sense of having been treated poorly, indeed somewhat like a lowly servant. Moreover, it was wholly unsuitable for public display. He clearly felt that while financial remuneration might in some way compensate for his time and effort, the political significance of his decoding could only be justly rewarded by something of greater and more visible significance, such as preferment to high ecclesiastical office. But instead of elevation to a bishopric, his services were effectively bought off like those of a public servant. It was precisely this comparatively low status of a government employee which had over the years become increasingly incompatible with that of his university professorship, no doubt adding to his desire for higher office. While he enjoyed a high reputation in the Republic of Letters and, as Keeper of the Archives, was regarded as one of the most senior officers of the University of Oxford, particularly through his unstinting efforts to defend that institution's ancient rights and privileges, neither his professorial post nor the office of Custos archivorum could rival the esteem conferred by a high-ranking position in the Anglican church.

By late summer 1691, Wallis felt moved to complain to the influential whig politician William Harbord about the incommensurability of the reward he had received with the significance of the intelligence he had provided. To reinforce this claim, he suggested that frustrating the French plan in Poland »was of much greater advantage to his Majestie and his Allies, than all that I am like to receive on that account«. Wallis would have been aware of the growing number of attacks at this time by whig politicians on principal tory ministers such as Nottingham and Thomas Osborne, marquis of Carmarthen, and it therefore made sense that he should address his anger to their political opponents. ${ }^{82}$ Nor was the problem of the unduly high

81 Wallis to Finch, 20 February/[2 March] 1689/90, London, British Library Add. MS 32499, f. 197; Smith: »John Wallis as eryptographerCryptographer«, pp. 89-90.

82 See Gilbert Burnet: History of his own Time: with speaker-Speaker Onslow, and dean-Dean Swift, 6 vols., Oxford ${ }^{2} 1833$, vol. IV, pp. 3-5; Henry Horwita: Parliament, Policy and Politics in the Reign of William III, Manchester 1977, p. 70. 
demand made on his services particularly new, for as he also points out during the two years since he first received intercepted French letters from Nottingham and the chancellor of exchequer Richard Hampden, these two men had kept him in almost continual employment. Hampden, a leading whig, had been concerned to promote financial measures aimed at supporting the war with France and was therefore keen to make use of Wallis's skills in revealing Louis XIV's political and military plans. ${ }^{83}$ Another of the officials to whom Wallis at this time expressed his discontent was Johnston, but this time the target was Frederick III. Accepting that he did not enter into a contract with the elector of Brandenburg, Wallis nonetheless suggests to Johnston that in view of the quantity of decoding work he had done and the significance of what he had revealed, he should have received a more appropriate form of remuneration than what had been offered:

»Yet when I had deciphered for them between two and three hundred sheets of very difficult and very different cyphers, they might at least have afforded me porter's pay, if not that of a scrivener. I did not contract with them, but did it frankly; for, having a Prince to deal with, I was to presume he would deal like himself. $\ll^{84}$

Unfortunately, Johnston, even if he might have been willing to take Wallis's case further, had already been appointed secretary of state in Scotland and therefore now had rather different concerns than in his earlier capacity as ambassador. ${ }^{85}$ At the same time, those figures who counted most, like Nottingham and his successor, Charles Talbot, duke of Shrewsbury, were concerned not to lose the services of the man on whom so much of their intelligence provision rested. Wallis's preferment to high office would have been the surest way to do precisely that.

\section{Conclusion}

Wallis possessed remarkable rhetorical skills which he could and did deploy to considerable effect whenever he felt he had been wronged. However, in accusing those who had employed his services in decoding the secret correspondence of Louis XIV of having exploited his loyalty and

83 See Burnet: History of his own Time, vol. IV, p. 28.

84 Wallis to Johnston, 9/[19] June 1692, in: The Gentleman's Magazine 58 (1778), Pt. II, No. 3 (September), pp. 759-60760.

85 Richard L. Greaves: Secrets of the Kingdom. British Radicals from the Popish Plot to the Revolution of $1688-$ 89, Stanford 1992, p. 341; Burnett: History of his own Time, vol. IV, p. 155. 
good-will he failed to recognize the complexities of court politics. Here Wallis's intellectual brilliance and scholarly prowess counted for little, as he ultimately discovered through absence of any noteworthy result from his complaints. Put simply, in contrast to mid-century he increasingly lacked influence at a time when a new political order emerged, to be more precise, when the king ceased to build his policies on whig support and moved instead towards the tories. Understandably, Wallis reserved his greatest anger for the office of the secretary of state, but Nottingham enjoyed ample royal favour. Having seen how so many lesser contemporaries had enjoyed patronage and preferment since the Restoration, Wallis was not impressed by the occasional royal bounty of fifty pounds. His response to finding his patience and loyalty requited in occasional payments of money was to deploy his rhetorical brilliance to the full. Breaking social convention, he questions the integrity of the Earl of Nottingham, who over the years had promised him so much:

\begin{abstract}
"'Tis true; I have had all along a great many good words; That he is my humble servant; My faithful servant; my very faithful servant; That he will not fail to acquaint the King with my diligence \& success in this difficult matter; That he is very sensible of the pains I had taken in this troublesome work; That he shall be very glad of any opportunity of doing me any service: That the King is sensible of my zeal \& good affection, and will (he beleeves) in a short time give me some mark of his favour (meaning, I suppose, some preferment,) wherein his Lordships endeavour shal not be wanting; That he will not be wanting to represent my services to my advantage. And the like. But these Promises are of Two-years standing. And it may seem strange; if in all that time (while so many Deans, \& Bishops, \& Arch Bishops have been made) his Lordship could never find an opportunity of what he so much desired. $\ll^{86}$
\end{abstract}

Such evident frustration was primarily born of the sheer quantity of ciphers which the aging Wallis was required to deal with after the Glorious Revolution of 1688-9/89. Added to that frustration was possibly also the awareness that the decipherer could never be quite as disinterested as Scott's dictum had suggested. Wallis's academic career had been largely built on the basis of assistance he had provided in revealing the plans of men he knew to have similar religious beliefs and political values to his own. Admittedly, those plans were rebellious and therefore beyond anything Wallis would have condoned, but the actors were his ideological

86 Wallis to Harbord, 15/[25] August 1691, British Library, Add. MS 32499, f. 283 ${ }^{\text {r }}$. In the space of six months, six bishoprics became vacant: Salisbury, Chester, Bangor, Worcester, Chichester, and Bristol. See Burnett: History of his own Time, vol. IV, p. 51. 
kinsfolk, no strangers or natural opponents. He was never able to free himself entirely from this past.

As this investigation has shown, the academic career of John Wallis was more than anything else founded upon his remarkable ability to decipher encoded political and military intelligence. Discovered during the height of the Civil Wars, this »jewell for a Princes use« was employed to advantage by parliamentary forces fearful of adversaries inside and outside government. It was principally Wallis's support in thwarting the Presbyterian plot of 1649-51-1651 which led to his being offered a Savilian professorship at Oxford. His expertise as decoder stood him in good stead, too, after the Restoration and was perhaps the single most important factor ensuring that he remained in post at the University right up until the end of his life. But academic security was bought at a price. As a decipherer Wallis was required to exercise discretion and to show unremitting loyalty. Above all, he was always a servant of the sovereign, and a succession of courtiers and government officers left him under no illusion as to how the vectors of power were set out. His desire for preferment was irreconcilable with the dictates of political reason, specifically with the need for him to be at the constant disposal of the state's intelligence needs.

Within the Republic of Letters things were quite different, his name was well respected, his books and articles read and cited by contemporaries, his network of correspondents the most extensive of any English scholar of the seventeenth century. Not only on account of his scholarly reputation within the University and as a member of the Royal Society, but also as one of Oxford's most senior officers he was a figure who commanded respect and was seldom subjected to the will of others.

Perhaps the most difficult task of all was for Wallis to combine life in these two spheres and one senses that for all his mental dexterity and rhetorical brilliance it was a task which necessarily remained irresolvable to the end. As a servant it was not up to him to dictate terms or to try to exert political influence - the fate of his erstwhile superior Thomas Scot served as a dreadful example.

Ironically, it was only when Leibniz, frustrated at Wallis's reluctance to provide the learned world with any insight into his methods of deciphering, proposed instead that the Savilian professor train suitable young men from Germany or elsewhere in his Ars deciphrandi, so that this art might not die with him, that things changed. Leibniz, arguing that Wallis's art should not 
be allowed to die with him, began what can be best described as a campaign to obtain funds for this promising project, addressing specifically the Swedish court ${ }^{87}$, the Elector of Brandenburg ${ }^{88}$, and the crown prince of Tuscany ${ }^{89}$. On 7 March 1699, he presented his proposal at a conference of the house of Brunswick-Lüneburg, describing Wallis as »the most famous decipherer now living in Europe«. After he had informed those present that Wallis was an excellent mathematician and was in correspondence with him, he proceeded to express his concern that the elderly Wallis might take his knowledge of decoding with him to the grave:

\footnotetext{
»Since he is now a man of eighty years and it is to be feared that the great things he has achieved in this art will be lost with him, I have remonstrated with him for the public good on many occasions that he finally be prepared to instruct in this one or other young man who may be found here and who is blessed with similar inclination to calculation and effort. $\ll^{90}$
}

Leibniz naturally did not fail to inform Wallis personally of this idea; in fact he had mentioned it already in his letter of March 1697. Skilfully, Wallis puts this information into the public sphere at a time when the question of financial or other reward was once more up for discussion in his correspondence with government officials. In an opportune letter to the Archbishop of Canterbury, Thomas Tenison, Wallis lets it be known that »he hath been sollicited more than once«, by letters from Leibniz, writing on behalf of the elector of Hannover, who was willing to send some persons to England to be instructed in the art by him..${ }^{91}$ In fact, Leibniz had not been

87 Leibniz to Sparwenfeld, 7/[17] April 1699, in: A I, 16, p. 726.

88 Leibniz to Fuchs, 14/[24] February 1699, in: Hbidibid., pp. 577-8578; Beeley: »Un de mes amis«, pp. 74-575.

89 Leibniz to Ferdinand of Tuscany, 24 October/[3 November] 1698, in: A I, 16, pp. 250-1251; Leibniz to Ferdinand of Tuscany, 20/30 September 1699, in: A I, 17, pp. 526-8료, 527; Leibniz to Ferdinand of Tuscany, [18]/28 December 1699, in: łbidibid., p. 727.

90 G. W. Leibniz: Promemoria fiir die geheimen Räte in Celle und Hannover, 7/[17] March 1699, in: A I, 16, pp. 120-1121: »Es wird bekand seyn, daß der berühmteste Dechifrateur so iezo in Europa lebet, sich ip England finde. Es ist ein treflicher Mathematicus und stehet mit mir in Correspondenz. Weil es nun ein 80 jahriger Mann, und zubesorgen, daß ein großes so er gethan dieser Kunst hohes zubringen mit ihm verlohren gehen werde, so habe ihn mit vielen remonstrationen pro bono publico dahin vermocht, daß er sich endtlich erbothen, einen und andern hier zu bequemen mit einem zu dergleichen calculis und laboribus geneigten Genio begabten jungen Menschen darinn zu informiren, wo bey als er sich anfangs entschuldiget, daß die Kunst in praecepta generalia nicht zubringen, ich vorgeschlagen, daß die information durch exempla geschehen kondte, in dem der discipulus durch die vestigia solutionum jam factarum gefuhret, und ihm wie man dahinter kommen gewieß[en], mithin dadurch das liecht angezundet, und der methodus beygebracht wurde, welchen vorschlag er auch guth gefunden.«

91 [Charlett] to Tenison, 22 September/[3 October 1700], Oxford, Bodleian Library, MS Ballard 24, f. 9 $-10^{\mathrm{v}}$, $9^{\mathrm{r}}$ Although this letter has been copied by Arthur Charlett, and sent in his name, it is in fact from Wallis. See also 
as successful as Wallis suggests, or indeed as Leibniz had himself suggested. Both men knew the importance of diplomatic leverage. Carefully avoiding any suggestion of disloyalty, Wallis indicated to Tenison that while he was willing to help the elector, he did not feel it would be proper to make the art public without the English monarch's permission. Although Wallis was evidently himself concerned that his skills might die with him, he felt that not allowing knowledge of his techniques to go abroad was »preferable to any personal advantage which he may receive from a forraign Prince «. ${ }^{92}$ The subtext of his remarks was nevertheless clearly understood by those in power: the following year, Wallis was awarded a yearly pension of one hundred pounds by the King with the specific brief that he instruct his grandson in the art of deciphering. Neither Leibniz nor Wallis could have anticipated events fourteen years later. With Leibniz's assistance, the official post of decipherer was born and Wallis and William Blencowe were its first holders.

Wallis to Tilson, 20/[31] March 1700/401, London, British Library, Add. MS 32499, f. 373; Beeley: »Un de mes amis«, p. 75.

92 [Charlett] to Tenison, 22 September/[3 October 1700], Oxford, Bodleian Library, MS Ballard 24, f. $9^{\mathrm{r}}-10^{\mathrm{v}}, 9^{\mathrm{r}}$. 